\title{
A probable waterborne outbreak of cryptosporidiosis in the Sheffield area
}

\author{
BARBARA A. RUSH, P. A. CHAPMAN* and R. W. INESON† \\ Public Health Laboratory, Northern General Hospital, Herries Road, Sheffield S5 7AU and †Environmental \\ Health Department, Town Hall Chambers, Barkers Pool, Sheffield S1 1EN
}

\begin{abstract}
Summary. There was a marked peak in human cases of cryptosporidiosis in the Sheffield area in May and June 1986. Extensive epidemiological investigations failed to find a common source of food or a consistent history of animal contact, but did suggest that a waterborne outbreak of cryptosporidiosis may have occurred. Cryptosporidium oocysts were found in untreated water and in fish from a reservoir complex implicated by epidemiological analysis. Laboratory investigations confirmed that cattle on a farm adjacent to the reservoir complex were a possible source of contamination.
\end{abstract}

\section{Introduction}

The coccidian parasite, Cryptosporidium, is now recognised as an important intestinal pathogen causing acute diarrhoeal disease in man. ${ }^{1}$ The source of infection for man may be diverse. Infections in farm, domestic and laboratory animals are common, ${ }^{2-4}$ and early reports suggested that close contact with animals was the usual source of infection for man. ${ }^{5,6}$ Transmission of Cryptosporidium from animals to man via food and milk has been documented ${ }^{7,8}$ and person-to-person transmission of Cryptosporidium has been reported in hospitals and nurseries. ${ }^{9,10}$ Of major public health concern are reports, ${ }^{11,12}$ supported by epidemiological and environmental evidence, of possible transmission of Cryptosporidium via contaminated drinking water treated by conventional means to remove bacterial and viral pathogens.

In the Sheffield area, from late April to October 1986, we observed an increase in human cases of cryptosporidiosis, with a marked peak in May and June. No changes in laboratory methods for detecting cryptosporidium oocysts took place at that time. Extensive epidemiological investigations by Sheffield Environmental Health Department (EHD) failed to find a common source of food or milk, or a consistent history of close contact with animals. However, of 62 patients recognised in May or June, $49(79 \%)$ drank water from the same reservoir complex.

The purpose of this study was to determine

Received 6 Nov. 1989; accepted 15 Jan. 1990.

* Correspondence should be sent to Mr P. A. Chapman. whether the hypothesis of a waterborne outbreak of cryptosporidiosis in Sheffield could be supported.

\section{Materials and methods}

\section{Selection of samples}

Man. All faecal samples from human cases of acute diarrhoea submitted to Sheffield Public Health Laboratory (PHL) between January 1985 and December 1987 were examined for oocysts of Cryptosporidium and for other recognised intestinal pathogens.

Cattle. Faecal samples from cattle on a farm adjacent to the implicated reservoir complex were taken by the Veterinary Investigations Centre (VIC), Loughborough, where smears were stained by a modified Ziehl-Neelsen (ZN) method, and examined microscopically.

Fish. Wild brown trout (Salmo trutta) were netted from the reservoir complex by the Yorkshire Water Authority (YWA). Intestinal contents were removed into sterile universal containers and examined at Sheffield PHL.

Water. Pre- and post-treatment samples of water (10 or $20 \mathrm{~L}$ depending on turbidity) were collected by YWA from the two reservoirs in the complex, feeder streams flowing into the reservoirs, a river flowing out of the reservoirs, and children's paddling pools fed by the latter river. Water samples were examined at Sheffield PHL.

\section{Examination of faecal samples}

All human faecal and fish intestinal samples were examined for oocysts of Cryptosporidium by microscopic examination of a direct smear stained by a modified $\mathrm{ZN}$ method. ${ }^{13}$ Samples containing bodies resembling such oocysts were tested by a direct immunofluorescence (IF) method, with mouse IgM monoclonal antibody (MAb) 
conjugated to fluorescein isothiocyanate (FITC) ${ }^{14}$ supplied by the Division of Microbiological Reagents and Quality Control (DMRQC), Central PHL, London.

All human faecal samples were examined also for various other intestinal pathogens by methods described previously. ${ }^{15,16}$ Fish intestinal samples were examined also by an enzyme immunoassay (EIA) for Cryptosporidium described below.

\section{Examination of water samples}

Water samples were passed through membrane filters (142 mm diameter, $0.45 \mu \mathrm{m}$ pore size; Pall Process Filtration Ltd) in a Sartorius filtration system (Sartorius, West Germany). Specimens containing much debris were allowed to settle overnight at $4^{\circ} \mathrm{C}$ before membrane filtration of the supernate. Filters were cut into strips, placed in a sterile jar and shaken vigorously with $100 \mathrm{ml}$ of phosphate-buffered saline pH 7.2 (PBS) containing Tween $801 \% \mathrm{v} / \mathrm{v}$. The suspensions were left overnight at $4^{\circ} \mathrm{C}$ and centrifuged at $3000 \mathrm{~g}$ for $20 \mathrm{~min}$ at $10^{\circ} \mathrm{C}$. The deposits were then examined for oocysts of Cryptosporidium by microscopy as above, and also by an EIA for Cryptosporidium as below.

\section{EIA for Cryptosporidium}

The assay, described fully in another report, ${ }^{17}$ was briefly as follows: $96-w e l l$ polystyrene EIA plates were coated with MAb to Cryptosporidium; uncoated sites were blocked by bovine serum proteins; samples of faecal suspension or water deposit were added and any cryptosporidium antigen allowed to react with the $\mathrm{MAb}$; MAb to Cryptosporidium, conjugated to FITC, was added to react with the cryptosporidium antigen; MAb against FITC, conjugated to horseradish peroxidase, was added to react with the FITC; peroxidase activity was measured with the chromogenic substrate $3: 3^{\prime} 5,5^{\prime}$ tetramethylbenzidine. Between stages, plates were washed three times with PBS containing Tween $200.5 \% \mathrm{v} / \mathrm{v}$. All antibodies and conjugates were supplied by DMRQC, and were used at their optimal dilutions.

\section{Statistical analysis}

For specimens sent to Sheffield PHL in May and June 1986, $\chi^{2}$ analysis was used to compare the incidence of cryptosporidiosis with the incidence of all diarrhoeal illness, in patients receiving drinking water from the

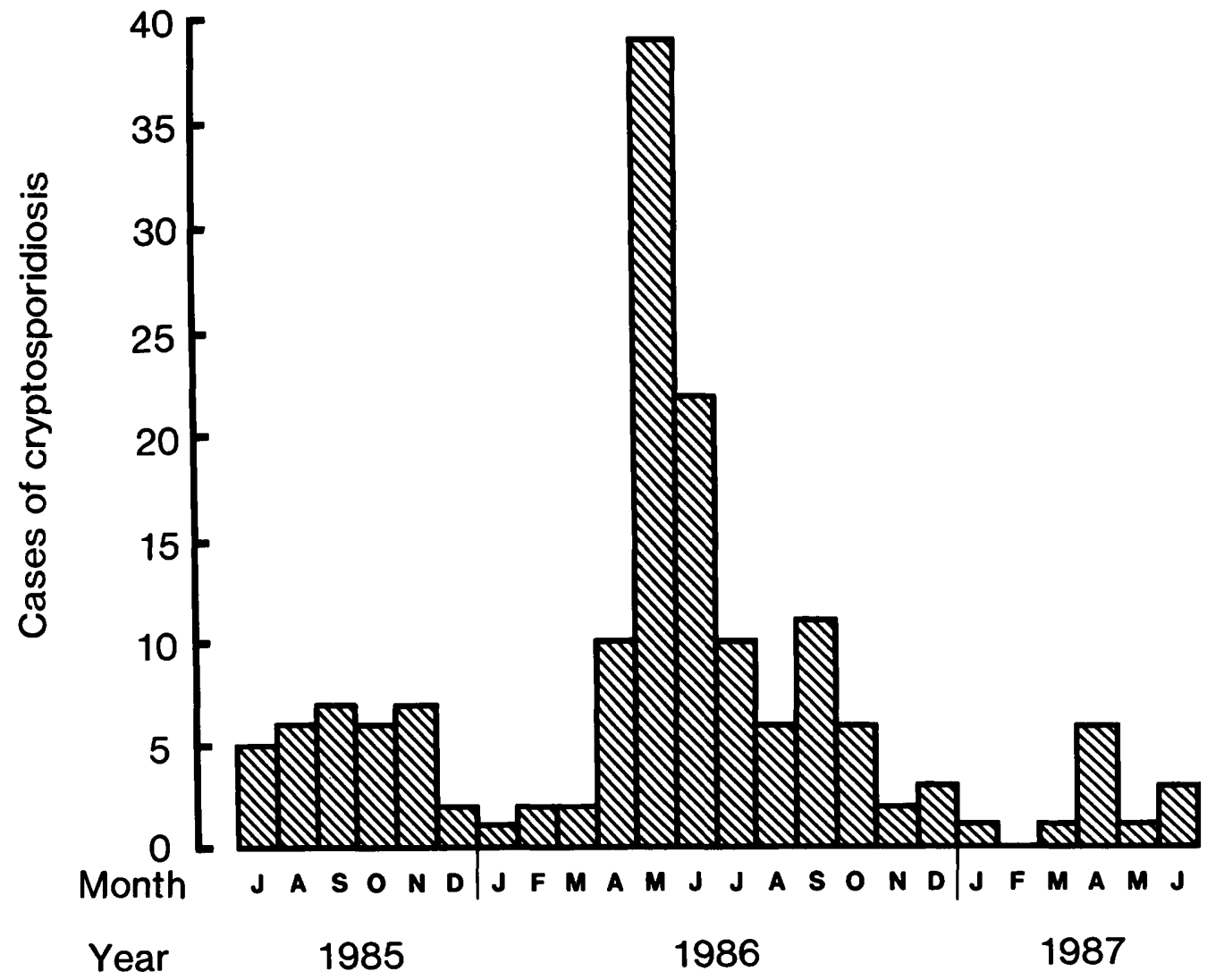

Figure. Monthly incidence of cryptosporidiosis in Sheffield. 
reservoir complex, and in those receiving water from other sources.

\section{Results}

\section{Detection of cryptosporidium oocysts}

Man. The figure shows the monthly numbers of cases of cryptosporidiosis from July 1985 to June 1987, with a marked peak in May and June 1986. Analysis of the data from this peak period showed a significant association of cryptosporidiosis with the supply of drinking water from the suspect reservoir complex (table I).

Of 935 human faecal samples examined in May and June 1986, 284 contained a recognised intestinal pathogen; of these, $62(22 \%)$ were Cryptosporidium.

Cattle. In a verbal report, the VIC indicated that most of the samples of cattle faeces contained oocysts of Cryptosporidium; unfortunately precise figures were not available.

Fish. Cryptosporidium oocysts, morphologically indistinguishable from those found in the human and bovine faecal samples, were found in the intestinal contents of apparently healthy brown trout. Of 18 specimens, seven were positive by both microscopy and EIA, two by microscopy alone and five by EIA alone (table II).

Water. Oocysts of Cryptosporidium were found in 14 untreated water samples from the two reservoirs, and in water samples from the streams and the river, but were not found in two samples of treated water (table II).

\section{Discussion}

The results suggest that there may have been a waterborne outbreak of cryptosporidiosis in Sheffield in May and June 1986. Cattle are a welldocumented source of cryptosporidium oocysts, ${ }^{3,18}$ and contamination of the reservoir system from this source most probably occurred from surface water after heavy rainfall. Water treatment that
Table I. Cases of cryptosporidiosis and acute diarrhoea during May and June 1986 in relation to water supply

\begin{tabular}{c|cc}
\hline & $\begin{array}{c}\text { Number of patients re- } \\
\text { ceiving drinking water } \\
\text { from }\end{array}$ \\
\cline { 2 - 2 } Patients & $\begin{array}{c}\text { suspect } \\
\text { reservoirs } \quad \begin{array}{c}\text { other } \\
\text { supply }\end{array}\end{array}$ \\
\hline $\begin{array}{c}\text { Confirmed cases of } \\
\text { cryptosporidiosis } \\
\begin{array}{c}\text { Cases of acute } \\
\text { diarrhoea }\end{array}\end{array}$ & $49^{*}$ & 13 \\
\hline
\end{tabular}

* Significant association of cryptosporidiosis with supply from suspect reservoirs $\left(\chi^{2}=11 \cdot 51, v=1, p<\right.$ $=0.001$ ).

eliminates bacterial and viral pathogens may allow viable oocysts to survive, so that water implicated in outbreaks of cryptosporidiosis may meet coliform and turbidity standards for drinking water. ${ }^{19}$ Therefore, examination for oocysts in water would be a necessary though laborious and costly procedure to minimise the risk of waterborne cryptosporidiosis. Various filtration and separation methods have been described, but oocysts so obtained often have altered morphology and react poorly in conventional and IF staining procedures. ${ }^{20-22}$ Better methods of detecting oocysts are needed.

Reports of Cryptosporidium in fish are uncommon. ${ }^{23}$ The significance of our finding of cryptosporidium oocysts, morphologically indistinguishable from those found in man, in apparently healthy brown trout, is unclear. It does, however, confirm the widespread presence of the organism in the water catchment system.

We did not find oocysts in two samples of treated water from the reservoir complex in early 1987. This may suggest that routine treatment procedures reduce the level of contamination below the limits of detection of the available methods. However, it

Table II. Detection of Cryptosporidium in environmental samples

\begin{tabular}{|c|c|c|c|c|}
\hline \multirow[b]{2}{*}{$\begin{array}{l}\text { Nature of specimen } \\
\text { (number of samples) }\end{array}$} & \multicolumn{4}{|c|}{ Number of samples in which oocysts were detected by } \\
\hline & $\begin{array}{c}\text { microscopy } \\
\text { and EIA }\end{array}$ & $\begin{array}{l}\text { microscopy } \\
\text { alone }\end{array}$ & $\begin{array}{c}\text { EIA } \\
\text { alone }\end{array}$ & $\begin{array}{l}\text { neither } \\
\text { method }\end{array}$ \\
\hline Surface water from reservoirs A and B (14) & 10 & 0 & 4 & 0 \\
\hline Treated drinking water from reservoir $\mathrm{A}$ (1) & 0 & 0 & 0 & 1 \\
\hline Treated drinking water from reservoir B (1) & 0 & 0 & 0 & 1 \\
\hline Brown trout intestinal contents (18) & 7 & 2 & 5 & 4 \\
\hline
\end{tabular}


is possible that a treatment failure may have occurred early in 1986, which was either unnoticed or had been rectified before a waterborne outbreak was suspected and water samples examined for oocysts. The water was examined some 6 months after the peak of the putative outbreak, when the incidence had fallen to the normal endemic rate and there was no association with the water supply.

Although the infective dose for man is not known, ingestion of as few as 10 oocysts may cause cryptosporidiosis in primates. ${ }^{24}$ Even small numbers of oocysts in drinking water must, therefore, be considered a potential hazard. Oocysts may be reduced in number, but not completely removed, by normal water filtration methods $;{ }^{12,20}$ they are resistant to many disinfectants ${ }^{18}$ and probably to

\section{REFERENCES}

1. Chapman PA. Cryptosporidiosis: recent trends in epidemiology, diagnosis and treatment. Serodiagn Immunother. Infect Dis 1988; 2: 311-317.

2. Pohlenz J, Moon HW, Cheville NF, Bemrick WJ. Cryptosporidiosis as a probable factor in neonatal diarrhoea of calves. J Am Vet Med Assoc 1978; 172: 452-457.

3. Tzipori S. Cryptosporidiosis in animals and humans. Microbiol Rev 1983; 47: 84-96.

4. Bennett M, Baxby D, Blundell N, Gaskell CJ, Hart CA, Kelly DF. Cryptosporidiosis in the domestic cat. Vet Rec 1985; 116: 73-74.

5. Anderson BC, Hall RF. Cryptosporidial infection in Idaho dairy calves. J Am Vet Med Assoc 1982; 181 : 484-485.

6. Reese NC, Current WL, Ernst JV, Bailey WS. Cryptosporidiosis of man and calf: a case report and results of experimental infections in mice and rats. Am J Trop Med Hyg 1982; 31 : 226-229.

7. Casemore DP, Jessop EG, Douce D, Jackson FB. Cryptosporidium plus Campylobacter: an outbreak in a semirural population. J Hyg (Lond) 1986; 96: 95-105.

8. Freidank H, Kist M. Cryptosporidia in immunocompetent patients with gastroenteritis. Eur J Clin Microbiol 1986; 6: 56-59.

9. Baxby D, Hart CA, Taylor C. Human cryptosporidiosis: a possible case of human cross infection. $\mathrm{Br}$ Med J 1983; 287: 1760-1761.

10. Wiedermann BL, Kaplan SL, Marino B. Prevalence and significance of cryptosporidiosis in children. Pediatr Infect Dis J 1985; 4: 292-293.

11. D'Antonio RG, Winn RE, Taylor JP et al. A waterborne outbreak of cryptosporidiosis in normal hosts. Ann Intern Med 1985; 103: 886-888.

12. Isaac-Renton JL, Fogel D, Stibbs HH, Ongerth JE. Giardia and Cryptosporidium in drinking water. Lancet 1987; 1 : 973-974.

13. Garcia LS, Bruckner DA, Brewer TC, Shimizu RY. Techniques for the recovery and identification of Cryptosporidium oocysts from stool specimens. J Clin Microbiol 1983; 18: 185-190.

14. McLauchlin J, Casemore DP, Harrison TG, Gerson PJ, routine chemical treatment, and they may remain viable in water at $4^{\circ} \mathrm{C}$ for at least 140 days. ${ }^{25}$

The present findings support the hypothesis, though do not prove, that a waterborne outbreak of cryptosporidiosis occurred in Sheffield during 1986. Increased awareness of the possibility of waterborne spread of Cryptosporidium, and better methods for detecting oocysts in environmental samples, would help in the investigation of future outbreaks.

We thank D. Smith and S. King of YWA and the staff of Sheffield PHL and Sheffield EHD for their help in these investigations; DMRQC, Central PHL, London, for supplying IF and EIA reagents; and Professor B. I. Duerden, Sheffield University Medical School, for helpful advice during the preparation of this manuscript.

Samuel D, Taylor AG. Identification of Cryptosporidium oocysts by monoclonal antibody. Lancet 1987; $1: 51$.

15. Chapman PA, Mitchelmore DL. A two-year survey of the incidence of heat-labile enterotoxin-producing Escherichia coli and other enteric pathogens in travellers returning to the Sheffield area. Epidemiol Infect 1988; 101: 239-247.

16. Chapman PA, Wright DJ, Norman P. Verotoxin-producing Escherichia coli infections in Sheffield: cattle as a possible source. Epidemiol Infect 1989; 102 : 439-445.

17. Chapman PA, Rush BA, McLauchlin J. An enzyme immunoassay for detecting Cryptosporidium in faecal and environmental samples. J Med Microbiol 1990; 32 : 233-237.

18. Angus $\mathrm{KW}$. Cryptosporidiosis in man, domestic animals and birds: a review. J Roy Soc Med 1983; 76: 62-70.

19. Logsdon GS. Evaluating treatment plants for particulate contaminant removal. J Am Water Workers Assoc 1987; 79 (No. 9) : 82-92.

20. Rose JB, Cifrino A, Madore MS, Gerba CP, Sterling CR, Arrowood MJ. Detection of Cryptosporidium from waste-water and fresh-water environments. Water Sci Technol 1986; 18: 233-239.

21. Musial CE, Arrowood MJ, Sterling CR, Gerba CP. Detection of Cryptosporidium in water using polypropylene cartridge filters. Appl Environ Microbiol 1987; 53: $687-692$.

22. Ongerth JE, Stibbs HH. Identification of Cryptosporidium oocysts in river water. Appl Environ Microbiol 1987; 53: 672-676.

23. Hoover DM, Hoerr FJ, Carlton WW, Hinsman EJ, Ferguson HW. Enteric cryptosporidiosis in a naso tang, Naso literatus Bloch and Schneider. J Fish Dis 1981; 4: 425-428.

24. Miller RA, Brondson MA, Morton WR. Determination of the infectious dose of Cryptosporidium and the influence of inoculum size on disease severity in a primate model. Proceedings of the 1986 Annual Meeting of the American Society for Microbiology, Washington DC, USA, p 49, B-148.

25. Current WL. Cryptosporidium: It's biology and potential for environmental transmission. CRC Crit Rev Environ Control 1986; $17: 21-51$. 